\title{
Integration of Agronomic Practices with Herbicides for Sustainable Weed Management in Aerobic Rice
}

\author{
M. P. Anwar, ${ }^{1,2}$ A. S. Juraimi, ${ }^{3}$ M. T. M. Mohamed, ${ }^{1,3}$ M. K. Uddin, ${ }^{3}$ \\ B. Samedani, ${ }^{3}$ A. Puteh, ${ }^{3}$ and Azmi Man ${ }^{4}$ \\ ${ }^{1}$ Institute of Tropical Agriculture, Universiti Putra Malaysia, 43400 Serdang, Selangor, Malaysia \\ ${ }^{2}$ Department of Agronomy, Bangladesh Agricultural University, Mymensingh 2202, Bangladesh \\ ${ }^{3}$ Department of Crop Science, Universiti Putra Malaysia, 43400 Serdang, Selangor, Malaysia \\ ${ }^{4}$ Malaysian Agricultural Research and Development Institute, 50774 Kuala Lumpur, Malaysia
}

Correspondence should be addressed to M. P. Anwar; parvezagron@yahoo.com

Received 6 July 2013; Accepted 27 August 2013

Academic Editors: T. Brock, R. Julliard, and S. Rossi

Copyright (C) 2013 M. P. Anwar et al. This is an open access article distributed under the Creative Commons Attribution License, which permits unrestricted use, distribution, and reproduction in any medium, provided the original work is properly cited.

\begin{abstract}
Till now, herbicide seems to be a cost effective tool from an agronomic view point to control weeds. But long term efficacy and sustainability issues are the driving forces behind the reconsideration of herbicide dependent weed management strategy in rice. This demands reappearance of physical and cultural management options combined with judicious herbicide application in a more comprehensive and integrated way. Keeping those in mind, some agronomic tools along with different manual weeding and herbicides combinations were evaluated for their weed control efficacy in rice under aerobic soil conditions. Combination of competitive variety, higher seeding rate, and seed priming resulted in more competitive cropping system in favor of rice, which was reflected in lower weed pressure, higher weed control efficiency, and better yield. Most of the herbicides exhibited excellent weed control efficiency. Treatments comprising only herbicides required less cost involvement but produced higher net benefit. On the contrary, treatments comprising both herbicide and manual weeding required high cost involvement and thus produced lower net benefit. Therefore, adoption of competitive rice variety, higher seed rate, and seed priming along with spraying different earlypostemergence herbicides in rotation at 10 days after seeding (DAS) followed by a manual weeding at 30 DAS may be recommended from sustainability view point.
\end{abstract}

\section{Introduction}

Weeds are endemic in crops [1] and a constant problem in crop production because of their dynamic nature [2]. Despite modern control practices aimed at weed elimination, weed continues to be a ubiquitous and recurrent threat for crop production due to its ability to shift in response to management practices and environmental conditions [3]. Because of the diversity and plasticity of weed communities, weed management should include diverse approaches and to be viewed as a continuous process [2]. Physical, cultural, and biological weed management was the only weed control strategy till 1940s. Since the introduction of herbicides, their amazing performance led to the belief that herbicide would solve the weed problem forever. But concern over the escalating problems of herbicide persistence and resistance in weeds and herbicide toxicity to crop has reinforced the need for alternative approaches [1]. Herbicides are often blamed for environmental pollution [4] and impoverishment of the natural flora and fauna in agro ecosystem [5]. Long term efficacy and sustainability issues are also the driving forces behind the reconsideration of herbicide dependent weed management.

In response to aforesaid problems, rice farming has been challenged to adopt a weed management strategy more respectful for environment. Weed management continues to be a huge challenge in aerobic rice which is highly vulnerable to weed infestation because of dry ploughing and aerobic soil conditions [6]. Proper weed management is considered to be one of the most important prerequisites to ensure satisfactory yield of rice $[7,8]$. High weed pressure in direct seeded rice lowers the economic return, and in extreme cases 
rice cultivation results in a losing concern [9]. This demands reappearance of physical, cultural, and biological weed management combined with judicious application of herbicides based on a thorough understanding in the crop-weed ecology, known as integrated weed management (IWM). The IWM is a component of integrated pest management which involves the integration of effective, environmentally safe, and socially acceptable control tactics that reduce weed interference below the economic injury level [10-13]. The IWM has got the potential to reduce herbicide use and to provide a robust and sustainable weed management [14]. The ultimate challenge towards developing an effective IWM is to create a cropping system unfavorable for weeds and favorable for crop [2].

Although weed management is herbicide dominated in many rice belts, there are strong indications that it will change in future [15]. Because farmers are now very much concerned about the advent of herbicide resistance and unwarranted environmental hazard, and therefore are becoming increasingly interested in less herbicide dependent weed management approach $[1,16]$, many farmers are using IWM approach for controlling weeds, but to some extent are hard to measure [11]. For the less herbicide dependent sustainable rice farming, IWM, has been emphasized by Azmi and Baki [17]. As stated by Jayadeva et al. [18], IWM can be successfully implemented in aerobic rice. None of the control measures in single can provide acceptable levels of weed control, and therefore, various components are to be integrated in a logical sequence [14]. Various agronomic tools like tillage, competitive cultivar, crop rotation, seeding date, seeding density, cover crop, and fertilizer management have been evaluated for their potentiality in managing weeds [19-23]. But all those tools may not work in every situation or with every weed/crop species [1]. Therefore, before integration, each of the components needs to be evaluated for their efficacy.

In rice, many studies have been conducted on IWM, most of which have looked at one or two of those components in isolation. Since the concept of aerobic rice is new, IWM issue is yet to be addressed properly considering the diverse weed management approaches. Therefore, for designing a sustainable weed management strategy for aerobic rice, it is a prerequisite to assess the simultaneous effect of different agronomic practices combined with timely herbicide application. The present study was, therefore, conducted to find out suitable herbicide and manual weeding combination(s) simultaneously incorporated with different agronomic practices to provide a comprehensive integrated weed management system for aerobic rice variety AERON 1.

\section{Materials and Methods}

2.1. Experimental Site and Soil. The field trials were conducted in main season 2010/2011 (November-January) and off season 2011 (May-July) at Universiti Putra Malaysia, Malaysia $\left(3^{\circ} 00^{\prime} 21.34^{\prime \prime} \mathrm{N}, 101^{\circ} 42^{\prime} 15.06^{\prime \prime} \mathrm{E}\right.$, and $37 \mathrm{~m}$ elevation). The experimental soil (Serdang series) was sandy clay loam in texture (56.77\% sand, $21.30 \%$ silt, and $21.93 \%$ clay) and acidic in reaction ( $\mathrm{pH} 5.6)$ with $1.42 \mathrm{~g} \mathrm{cc}^{-1}$ bulk

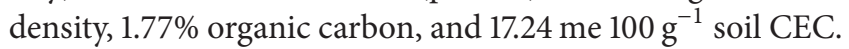
Soil contained $0.38 \%$ total N, 21.5 ppm available P, $139 \mathrm{ppm}$ available K, 803 ppm Ca, and 159 ppm Mg. At field capacity, soil water retention was $22.69 \%$ (wet basis) and $29.35 \%$ (dry basis). The local climate was hot humid tropic with plentiful rainfall. During the experimental period, average maximum and minimum temperatures, relative humidity, rainfall, evaporation, and sunshine hours ranged from 31.7 to $35.0^{\circ} \mathrm{C}$ and 22.9 to $24.4^{\circ} \mathrm{C}, 93.5$ to $94.7 \%, 3.8$ to $9.9 \mathrm{~mm}$ day $^{-1}$, 2.94 to $4.82 \mathrm{~mm} \mathrm{day}^{-1}$ and 3.95 to $6.97 \mathrm{hrs} \mathrm{day}^{-1}$, respectively.

2.2. Plant Material. Aerobic rice variety AERON 1 was used as the plant material in the present study. This variety is sourced from International Rice Research Institute (IRRI).

2.3. Experimental Treatments and Design. The experiment was laid out in a randomized complete block design with three replications. Fourteen different combinations of herbicides and manual weeding were evaluated for their efficacy in controlling weeds under aerobic soil conditions; seasonlong weed-free check and season-long weedy check were also included in the trial (Table 1). Herbicides included one preemergence (pretilachlor), five early-postemergence (cyhalofop-butyl, bensulfuron, bispyribac-sodium, propanil and thiobencarb), and two postemergence (bentazon and MCPA), which were available as six commercial products. Herbicides used in this experiment were selected based on their performances in the earlier study [24]. Season-long weed-free plots were maintained through manual weeding as and when necessary. In weedy checks, no weeding operations were done.

2.4. Integration of Agronomic Practices. Different agronomic tools were integrated in this study to create a more competitive condition in favor of rice and hence to achieve higher weed control efficiency. Aerobic rice variety AERON 1 was used as the plant material, since it was the most competitive and productive weed under aerobic soil conditions as found in the previous study [21]. A seeding rate of 300 seeds $/ \mathrm{m}^{2}$ was used for better weed competitiveness and higher yield as evident in the earlier study [22]. Based on the findings of the preceding study [25], rice seeds were primed by soaking in $1 \%$ Zappa solution for 24 hours followed by air drying for 12 hours to boost weed competitiveness through faster and higher emergence rate and increased seedling vigor. Timing of herbicide application and manual weeding was adjusted to match with the predetermined critical period of weed control of 20-43 days after seeding [26] at 10\% yield loss level.

2.5. Crop Husbandry. The soil was dry-ploughed and harrowed but not puddled during preparation. Rice seeds were directly dry-seeded at $2 \mathrm{~cm}$ depth in rows with $25 \mathrm{~cm}$ interrow and $15 \mathrm{~cm}$ intrarow spacing at the rate of 300 seeds $/ \mathrm{m}^{2}$. Each plot, of size $5 \mathrm{~m}$ long and $3 \mathrm{~m}$ wide, was fertilized with triple super phosphate (TSP) and muriate of potash (MP) at the rate of $100 \mathrm{~kg} \mathrm{P} / \mathrm{ha}$ and $100 \mathrm{~kg} \mathrm{~K} / \mathrm{ha}$, respectively, during final land preparation; urea was top dressed thrice each at the rate of $50 \mathrm{~kg} \mathrm{~N} / \mathrm{ha}$ at 2, 4, and 6 weeks after seeding. Soil was maintained under nonsaturated aerobic conditions throughout. The trial was primarily rain fed, but supplemental 
TABLE 1: List of weed control treatments used in the experiments in main season 2010/11 and off season 2011.

\begin{tabular}{|c|c|c|c|}
\hline Label & Treatments & Application rate & $\begin{array}{l}\text { Time } \\
\text { (DAS) }\end{array}$ \\
\hline $\mathrm{T} 1$ & Pretilachlor/safener fb bentazon/MCPA & $0.5 \mathrm{~kg}$ a.i. $/ \mathrm{ha} \mathrm{fb} 0.6 / 0.1 \mathrm{~kg}$ a.i. $/ \mathrm{ha}$ & $1 \mathrm{fb} 30$ \\
\hline $\mathrm{T} 2$ & Pretilachlor/safener fb MW & $0.5 \mathrm{~kg}$ a.i./ha & $10 \mathrm{fb} 30$ \\
\hline $\mathrm{T} 3$ & Pretilachlor/safener fb propanil/thiobencarb & $0.5 \mathrm{~kg}$ a.i. $/ \mathrm{ha} \mathrm{fb} 1.2 / 2.4 \mathrm{~kg}$ a.i. $/ \mathrm{ha}$ & $1 \mathrm{fb} 10$ \\
\hline $\mathrm{T} 4$ & $\begin{array}{l}\text { Pretilachlor/safener fb propanil/thiobencarb } \\
\text { fb bentazon/MCPA }\end{array}$ & $\begin{array}{l}0.5 \mathrm{~kg} \text { a.i. } / \mathrm{ha} \mathrm{fb} 1.2 / 2.4 \mathrm{~kg} \text { a.i. } / \mathrm{ha} \\
\mathrm{fb} 0.6 / 0.1 \mathrm{~kg} \text { a.i. } / \mathrm{ha}\end{array}$ & $1 \mathrm{fb} 10 \mathrm{fb} 30$ \\
\hline T5 & Pretilachlor/safener fb propanil/thiobencarb fb MW & $0.5 \mathrm{~kg}$ a.i. $/ \mathrm{ha}$ fb $1.2 / 2.4 \mathrm{~kg}$ a.i. $/ \mathrm{ha}$ & $1 \mathrm{fb} 10 \mathrm{fb} 30$ \\
\hline T6 & Propanil/thiobencarb & $1.2 / 2.4 \mathrm{~kg}$ a.i. $/ \mathrm{ha}$ & 10 \\
\hline T7 & Propanil/thiobencarb fb bentazon/MCPA & 1.2/2.4 kg a.i./ha fb. 0.6/0.1 kg a.i./ha & $10 \mathrm{fb} 30$ \\
\hline $\mathrm{T} 8$ & Propanil/thiobencarb $\mathrm{fb} \mathrm{MW}$ & $1.2 / 2.4 \mathrm{~kg}$ a.i. $/ \mathrm{ha}$ & $10 \mathrm{fb} 30$ \\
\hline T9 & Cyhalofop-butyl + bensulfuron & $0.1 \mathrm{~kg}$ a.i. $/ \mathrm{ha}+0.06 \mathrm{~kg}$ a.i $/ \mathrm{ha}$ & 10 \\
\hline $\mathrm{T} 10$ & Cyhalofop-butyl + bensulfuron fb bentazon/MCPA & $0.1 \mathrm{~kg}$ a.i. $/ \mathrm{ha}+0.06 \mathrm{~kg}$ a.i. $/ \mathrm{ha} \mathrm{fb} 0.6 / 0.1 \mathrm{~kg}$ a.i. $/ \mathrm{ha}$ & $10 \mathrm{fb} 30$ \\
\hline T11 & Cyhalofop-butyl + bensulfuron fb MW & $0.1 \mathrm{~kg}$ a.i. $/ \mathrm{ha}+0.06 \mathrm{~kg}$ a.i. $/ \mathrm{ha}$ & $10 \mathrm{fb} 30$ \\
\hline $\mathrm{T} 12$ & Bispyribac-sodium & $0.03 \mathrm{~kg}$ a.i. $/ \mathrm{ha}$ & 10 \\
\hline $\mathrm{T} 13$ & Bispyribac-sodium fb bentazon/MCPA & $0.03 \mathrm{~kg}$ a.i. $/ \mathrm{ha} \mathrm{fb} 0.6 / 0.1 \mathrm{~kg}$ a.i. $/ \mathrm{ha}$ & $10 \mathrm{fb} 30$ \\
\hline T14 & Bispyribac-sodium $\mathrm{fb} \mathrm{MW}$ & $0.03 \mathrm{~kg}$ a.i. $/ \mathrm{ha}$ & $10 \mathrm{fb} 30$ \\
\hline $\mathrm{T} 15$ & Season long weed-free & & Season long \\
\hline T16 & Season long weedy & & - \\
\hline
\end{tabular}

I: means that the herbicides were formulated as a proprietary mixture, + : means that the herbicides were tank-mixed and applied at the same time, all herbicides were applied as per manufacturers' recommended rates in $300 \mathrm{~L}$ of water per hectare by knapsack sprayer. DAS: days after seeding; fb: followed by.

sprinkler irrigation was given when hair-like cracks appeared on the soil surface. Overflow canals were kept to facilitate drainage following heavy rainfall to avoid ponding. Different intercultural operations and plant protection measures were taken following standard practices [27].

2.6. Weed Measurements. A $25 \mathrm{~cm} \times 25 \mathrm{~cm}$ quadrate was randomly placed lengthwise at four spots in each plot for recording of weed data at 10, 30, and 75 days after seeding (DAS). Weeds were clipped to ground level, identified and counted by species, and separately oven dried at $70^{\circ} \mathrm{C}$ for $72 \mathrm{~h}$. Weed density (WD) and weed dry weight (WDW) were expressed as no. $/ \mathrm{m}^{2}$ and $\mathrm{g} / \mathrm{m}^{2}$, respectively. Dominant weed species were identified using the summed dominance ratio (SDR) computed as follows [28]:

SDR of a weed species

$$
=\frac{[\text { Relative density }(\mathrm{RD})+\text { Relative dry weight }(\mathrm{RDW})]}{2},
$$

where

$$
\begin{aligned}
\mathrm{RD}(\%) & =\left(\frac{\text { Density of a given weed species }}{\text { Total weed density }}\right) \times 100, \\
\mathrm{RDW}(\%) & =\left(\frac{\text { Dry weight of a given weed species }}{\text { Total weed dry weight }}\right) \times 100 .
\end{aligned}
$$

Weed control rating was done visually at 7,14 , and 21 days after herbicide application (DAA) of each herbicide using a scale of 1 to 5 [29]. Weed control efficiency (WCE) of different herbicide treatments was calculated as follows [30]:

$$
\operatorname{WCE}(\%)=\frac{(\mathrm{DWC}-\mathrm{DWT})}{\mathrm{DWC}} \times 100,
$$

where

DWC $=$ dry weight of weeds in weedy check plots,

DWT $=$ dry weight of weeds in treated plots.

2.7. Rice Measurements. At maturity, yield attributes were recorded from ten randomly selected hills. All the panicles of sample hills were counted and converted to panicles $/ \mathrm{m}^{2}$. Sample panicles were hand threshed; filled grains were separated from unfilled grains and counted to calculate filled grains/panicle. Central $3 \mathrm{~m}^{2}$ area of each plot was hand harvested to record grain yield ( $\mathrm{t} / \mathrm{ha}$ ) and thousand-seed weight (g). Grain yield and thousand-seed weight were adjusted to $14 \%$ moisture content. Percent relative yield loss (RYL) due to weeds was calculated as $[100 \times$ (weed-free yield - weedy yield)/weed-free yield]. Crop phytotoxicity rating of different herbicides was assessed visually at 7, 14, and 21 days after application (DAA) of herbicide using a scale of 1 to 5 [29].

2.8. Economic Measurements. Economic analysis was performed following the procedure by Hussain et al. [31]. Two manual weedings were considered sufficient to keep the plots weed-free throughout. Laborers required for one round weeding and one round herbicide spraying per hectare were 50 and 2, respectively. The cost for laborer was Ringgit Malaysia (RM) 25/laborer/day. The cost of each herbicide was 
TABLE 2: Weed composition with summed dominance ratio (SDR) followed by standard error (SE) in off season 2010 and main season 2010/2011 as observed in season-long weedy check.

\begin{tabular}{|c|c|c|c|}
\hline \multirow{2}{*}{ Scientific name } & \multirow{2}{*}{ Family name } & \multicolumn{2}{|c|}{ SDR (SE) } \\
\hline & & $\begin{array}{c}\text { Main season } \\
2010 / 2011\end{array}$ & $\begin{array}{c}\text { Off season } \\
2011\end{array}$ \\
\hline \multicolumn{4}{|l|}{ Broadleaves } \\
\hline Physalis heterophylla Nees & Solanaceae & $18.36 \pm 6.4$ & $15.54 \pm 3.78$ \\
\hline Scoparia dulcis L. & Scrophulariaceae & $12.50 \pm 4.2$ & $10.32 \pm 3.41$ \\
\hline Cleome rutidosperma DC & Capparidaceae & $12.38 \pm 3.9$ & $9.30 \pm 1.45$ \\
\hline Jussiaea linifolia Vahl & Onagraceae & $5.63 \pm 1.2$ & $4.75 \pm 0.98$ \\
\hline Phyllanthus niruri L. & Euphorbiaceae & $4.84 \pm 0.9$ & $3.86 \pm 0.74$ \\
\hline Hedyatis corymbosa (L.) Lam. & Rubiaceae & $2.32 \pm 0.6$ & $2.56 \pm 0.22$ \\
\hline Mimosa pudica L. & Fabaceae & $1.98 \pm 0.58$ & $3.75 \pm 1.01$ \\
\hline Alternanthera sessilis (L.) R. Br. Ex DC. & Amaranthaceae & $1.25 \pm 0.25$ & $1.03 \pm 0.55$ \\
\hline Euphorbia hirta L. & Euphorbiaceae & $1.06 \pm 0.29$ & $2.58 \pm 0.73$ \\
\hline Emilia sonchifolia (L.) DC. Ex Wight & Asteraceae & $0.96 \pm 0.31$ & $1.40 \pm 0.56$ \\
\hline \multicolumn{4}{|l|}{ Sedges } \\
\hline Cyperus rotundus $\mathrm{L}$. & Cyperaceae & $8.77 \pm 2.76$ & $13.52 \pm 2.47$ \\
\hline Fimbristylis miliacea (L.) Vahl & Cyperaceae & $6.63 \pm 1.06$ & $3.17 \pm 1.30$ \\
\hline Cyperus sphacelatus Rottb. & Cyperaceae & - & $5.63 \pm 1.51$ \\
\hline Cyperus aromaticus & Cyperaceae & $3.91 \pm 0.65$ & $0.98 \pm 0.28$ \\
\hline \multicolumn{4}{|l|}{ Grasses } \\
\hline Eleusine indica (L.) Gaertn. & Poaceae & $7.88 \pm 3.10$ & $7.31 \pm 2.11$ \\
\hline Leptochloa chinensis (L.) Nees & Poaceae & $6.11 \pm 1.42$ & $9.21 \pm 2.44$ \\
\hline Echinochloa colona (L.) Link & Poaceae & $2.43 \pm 0.35$ & $4.56 \pm 1.02$ \\
\hline Digitaria ciliaris (Retz.) Koel & Poaceae & $2.67 \pm 0.80$ & - \\
\hline Axonopus compressus (Sw.) Beauv & Poaceae & $0.32 \pm 0.10$ & $0.53 \pm 0.12$ \\
\hline
\end{tabular}

estimated based on their local market price. Price of paddy was collected from different rice growing areas and was considered as RM 1000/t for calculating the gross return. The net benefit per hectare for each treatment was calculated by deducting the weed management cost from the gross return.

2.9. Statistical Analysis. All data were subjected to ANOVA by using SAS statistical software package version 9.1 [32]. Since treatment by season interaction was not significant, data were averaged across the seasons and were used in subsequent analysis. Significant differences among means were adjudged by using Fisher's protected least significant difference (LSD) test at $P \leq 0.05$. Simple regression analysis was conducted to quantify the relationship among different traits.

\section{Results}

3.1. Composition of Weed Flora. The study was conducted under naturally occurring mixed weed population. The experimental field was infested with broadleaf weeds, sedges, and grasses, and mostly dominated by broadleaf weeds. The weed community had a wide spectrum of 19 species representing 11 different families (Table 2). Among those, 17 species were prevalent in both main and off seasons. Further analysis showed that the relative composition of the broadleaf, sedges, and grasses were about 62,19 , and 19\%, respectively, in main season, while the respective values in off season were $55 \%$, $23 \%$, and $22 \%$.

3.2. Weed Control and Crop Toxicity Ratings. Weed control was rated visually at 7, 14, and 21 DAA of herbicide (Table 3 ). The rating showed that application of preemergence herbicide pretilachlor/safener resulted in excellent control of weeds at 7 DAA, but good and fair control at 14 and 21 DAA, respectively. On the other hand, early postemergence application of cyhalofop-butyl + bensulfuron and bispyribac-sodium provided excellent weed control at $21 \mathrm{DAA}$, although the ratings were fair at $7 \mathrm{DAA}$ and good at $14 \mathrm{DAA}$. Spraying with propanil/thiobencarb offered moderate weed control at $7 \mathrm{DAA}$ but good control both at 14 and $21 \mathrm{DAA}$. The only postemergence formulation bentazon/MCPA resulted in poor control at $7 \mathrm{DAA}$, fair control at $14 \mathrm{DAA}$, and excellent control at $21 \mathrm{DAA}$. Thus, weed control rating varied with course of time and herbicide formulation. In general, all the herbicides showed high selectivity to rice crop (Table 3 ). Among the herbicides, propanil/thiobencarb and cyhalofopbutyl + bensulfuron caused no visible injury to rice plant, while pretilachlor/safener, bispyribac-sodium, and bentazon/MCPA showed slight phytotoxicity to rice. hytotoxicity of pretilachlor/safener was characterized by minor reduction 
TABLE 3: Weed control rating and crop toxicity rating of different herbicides.

\begin{tabular}{|c|c|c|c|c|c|c|}
\hline \multirow[t]{2}{*}{ Herbicide } & \multicolumn{3}{|c|}{$\begin{array}{l}\text { Weed control rating } \\
\text { Days after } \\
\text { application }\end{array}$} & \multicolumn{3}{|c|}{$\begin{array}{l}\text { Phytotoxicity rating } \\
\text { Days after } \\
\text { application }\end{array}$} \\
\hline & 7 & 14 & 21 & 7 & 14 & 21 \\
\hline Pretilachlor/safener & 1 & 2 & 3 & 2 & 1 & 1 \\
\hline Propanil/thiobencarb & 3 & 2 & 2 & 1 & 1 & 1 \\
\hline $\begin{array}{l}\text { Cyhalofop-butyl + } \\
\text { bensulfuron }\end{array}$ & 3 & 2 & 1 & 1 & 1 & 1 \\
\hline Bispyribac-sodium & 3 & 2 & 1 & 1 & 2 & 1 \\
\hline Bentazon/MCPA & 4 & 3 & 1 & 2 & 2 & 1 \\
\hline
\end{tabular}

DAA: Days after application of herbicide; weed control rating: $1=$ excellent/satisfactory, 2 good, $3=$ fair, $4=$ poor, and $5=$ no/very poor control; phytotoxicity rating: $1=$ very slight injury, $2=$ slight injury, $3=$ phytotoxic, $4=$ severely phytotoxic, and $5=$ crop $100 \%$ killed.

in plant height and slight leaf chlorosis as observed at $7 \mathrm{DAA}$, while in case of Bispyribac-sodium and bentazon/MCPA, plant growth was stunted to some extent, and leaves failed to expand fully and became yellowish as noticed at 7 and 14 DAA. However, those symptoms could not persist up to crop harvest.

3.3. Weed Dry Weight and Density. Both weed dry weight and density were significantly influenced by weed control treatments at all the sampling dates (Table 4). At 10 DAS, that is, just before application of early-postemergence herbicides, only the plots sprayed with pretilachlor/safener produced lower weed dry weight and density compared to season-long weedy check. On an average, weed dry weight and density in pretilachlor/safener treated plots were $2 \mathrm{~g} / \mathrm{m}^{2}$ and 52 weeds $/ \mathrm{m}^{2}$, respectively, while for weedy check, the respective values were $>6 \mathrm{~g} / \mathrm{m}^{2}$ and 166 weeds $/ \mathrm{m}^{2}$. Hence, preemergence application of pretilachlor/safener reduced weed dry weight by $70 \%$ and weed density by $69 \%$ as compared to untreated weedy plots. Other weed control treatments comprising only early-post- with/without postemergence herbicides or manual weeding produced similar weed dry weight and density with season-long weedy check. Significant effect of different early-postemergence herbicides on weed dry weight and density was evident from the observations recorded at 30 DAS (prior to application of postemergence herbicide bentazon/MCPA or manual weeding) (Table 4). Reduction in weed dry weight and density due to application of different early-postemergence herbicides ranged from 40 to $90 \%$ and 39 to $90 \%$, respectively. Spraying with propanil/thiobencarb after pretilachlor/safener resulted in highest reduction (90\%) in weed dry weight and density, while the plots treated with Pretilachlor/safener registered the highest weed dry weight and density next to untreated weedy plots. The early-postemergence herbicides performed in the order of cyhalofop-butyl + bensulfuron $>$ propanil/thiobencarb $>$ bispyribac-sodium in terms of weed dry weight reduction. Weed control treatments exerted significant influence on weed dry weight and density at

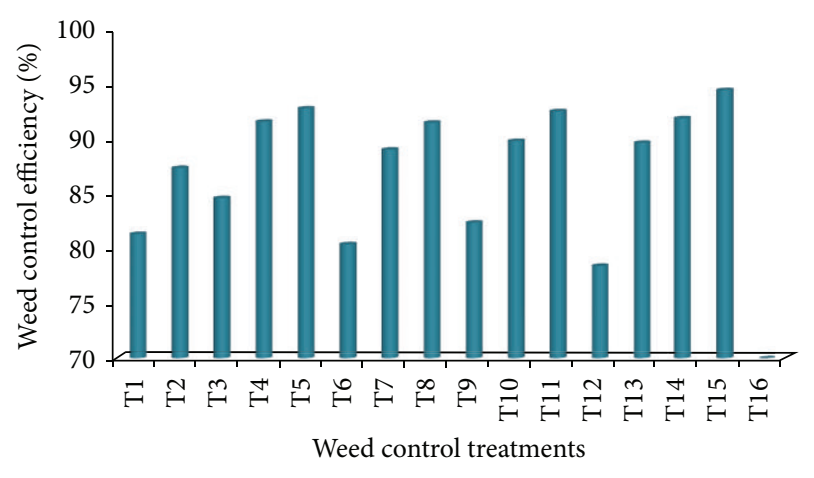

FIGURE 1: Weed control efficiency of different weed control treatments in aerobic rice variety AERON 1 (averaged over seasons). T1: pretilachlor/safener fb bentazon/MCPA; T2: pretilachlor/safener $\mathrm{fb}$ manual weeding; T3: pretilachlor/safener fb propanil/thiobencarb; T4: pretilachlor/safener $\mathrm{fb}$ propanil/thiobencarb $\mathrm{fb}$ bentazon/MCPA; T5: pretilachlor/safener fb propanil/thiobencarb $\mathrm{fb}$ manual weeding; T6: propanil/thiobencarb; T7: propanil/thiobencarb fb bentazon/MCPA; T8: propanil/thiobencarb fb manual weeding; T9: cyhalofop-butyl + bensulfuron; T10: cyhalofop-butyl + bensulfuron fb bentazon/MCPA; T11: cyhalofop-butyl + bensulfuron $\mathrm{fb}$ manual weeding; T12: bispyribac-sodium; T13: bispyribac-sodium $\mathrm{fb}$ bentazon/MCPA; T14: bispyribac-sodium $\mathrm{fb}$ manual weeding; T15: season long weed-free by manual weeding; T16: season long weedy.

75 DAS (Table 4). Most of the treatments provided excellent weed control while others performed satisfactorily. Weed dry weight in different weed control treatments ranged between 6.77 and $64.58 \mathrm{~g} / \mathrm{m}^{2}$ and density between 76.77 and 134 plants $/ \mathrm{m}^{2}$, while in weedy check the respective values were $328.51 \mathrm{~g} / \mathrm{m}^{2}$ and $299.50 \mathrm{plants} / \mathrm{m}^{2}$. Results showed that earlypostemergence application of any of the herbicides at 10 DAS followed by a manual weeding at 30 DAS or preemergence application of pretilachlor/safener at $1 \mathrm{DAS}$ followed by early-postemergence application of propanil/thiobencarb at 10 DAS followed by manual weeding/postemergence application of bentazon/MCPA at 30 DAS resulted in the lowest and identical weed dry weight and density. This negates the necessity of preemergence application. It is interesting to note that postemergence application of bentazon/MCPA at 30 DAS and manual weeding on the same day resulted in similar weed dry weight and density reduction irrespective of early-postemergence application. But bentazon/MCPA was found less effective than manual weeding when applied after preemergence application of pretilachlor/safener not followed by an early-postemergence application.

3.4. Weed Control Efficiency. The WCE based on the weed dry weight at harvest varied significantly among the weed control treatments (Figure 1). All the weed control treatments showed more than $80 \%$ WCE, and some treatments performed similar to season-long weed-free check with almost 98\% WCE. It is evident that pretilachlor/safener fb propanil/thiobencarb $\mathrm{fb}$ 
TABLE 4: Weed dry weight and weed density at different growth stages of rice variety AERON 1 as influenced by weed control treatments (averaged over seasons).

\begin{tabular}{|c|c|c|c|c|c|c|}
\hline \multirow{2}{*}{ Treatment } & \multicolumn{3}{|c|}{ Weed dry weight $\left(\mathrm{g} / \mathrm{m}^{2}\right)$} & \multicolumn{3}{|c|}{ Weed density $\left(\right.$ no. $\left./ \mathrm{m}^{2}\right)$} \\
\hline & 10 DAS & $30 \mathrm{DAS}$ & 75 DAS & 10 DAS & 30 DAS & 75 DAS \\
\hline $\mathrm{T} 1$ & $2.25^{\mathrm{b}}$ & $61.18^{\mathrm{b}, \mathrm{c}}$ & $52.89^{\mathrm{b}, \mathrm{c}}$ & $56.48^{\mathrm{b}}$ & $122.74^{\mathrm{b}, \mathrm{c}}$ & $124.89^{\mathrm{b}, \mathrm{c}}$ \\
\hline $\mathrm{T} 2$ & $1.87^{\mathrm{b}}$ & $63.40^{\mathrm{b}}$ & $28.66^{\mathrm{e}, \mathrm{f}}$ & $46.83^{\mathrm{b}}$ & $127.04^{\mathrm{b}}$ & $98.66^{\mathrm{e}, \mathrm{f}}$ \\
\hline T3 & $2.43^{\mathrm{b}}$ & $10.17^{\mathrm{f}, \mathrm{g}}$ & $39.68^{\mathrm{d}, \mathrm{e}}$ & $60.77^{\mathrm{b}}$ & $20.38^{\mathrm{f}}$ & $109.68^{\mathrm{d}, \mathrm{e}}$ \\
\hline $\mathrm{T} 4$ & $2.02^{\mathrm{b}}$ & $11.37^{\mathrm{f}}$ & $11.63^{g, j}$ & $50.65^{\mathrm{b}}$ & $22.78^{f}$ & $81.63^{g, h}$ \\
\hline T5 & $1.80^{\mathrm{b}}$ & $12.22^{\mathrm{f}}$ & $6.77^{\mathrm{i}, \mathrm{j}}$ & $44.93^{\mathrm{b}}$ & $24.41^{\mathrm{f}}$ & $76.77^{\mathrm{h}}$ \\
\hline T6 & $6.62^{\mathrm{a}}$ & $47.78^{\mathrm{d}, \mathrm{e}}$ & $56.65^{\mathrm{b}, \mathrm{c}}$ & $165.40^{\mathrm{a}}$ & $95.45^{\mathrm{d}, \mathrm{e}}$ & $126.65^{\mathrm{b}, \mathrm{c}}$ \\
\hline T7 & $6.53^{\mathrm{a}}$ & $44.59^{\mathrm{d}, \mathrm{e}}$ & $21.87^{\mathrm{f}, \mathrm{g}}$ & $163.18^{\mathrm{a}}$ & $89.01^{\mathrm{d}, \mathrm{e}}$ & $91.87^{\mathrm{f}, \mathrm{g}}$ \\
\hline T8 & $5.95^{\mathrm{a}}$ & $51.20^{\mathrm{c}, \mathrm{d}}$ & $11.98^{\mathrm{g}, \mathrm{j}}$ & $148.87^{\mathrm{a}}$ & $102.17^{\mathrm{d}}$ & $81.98^{\mathrm{g}, \mathrm{h}}$ \\
\hline T9 & $5.92^{\mathrm{a}}$ & $38.73^{\mathrm{e}}$ & $48.72^{\mathrm{c}, \mathrm{d}}$ & $148.05^{\mathrm{a}}$ & $77.34^{\mathrm{e}}$ & $118.72^{\mathrm{c}, \mathrm{d}}$ \\
\hline $\mathrm{T} 10$ & $6.55^{\mathrm{a}}$ & $42.43^{\mathrm{de}}$ & $18.73^{\mathrm{f}, \mathrm{i}}$ & $163.45^{\mathrm{a}}$ & $84.94^{\mathrm{d}, \mathrm{e}}$ & $88.73^{\mathrm{f}, \mathrm{h}}$ \\
\hline T11 & $6.42^{\mathrm{a}}$ & $44.43^{\mathrm{d}, \mathrm{e}}$ & $7.87^{h, j}$ & $160.68^{\mathrm{a}}$ & $88.94^{\mathrm{d}, \mathrm{e}}$ & $77.87^{\mathrm{h}}$ \\
\hline $\mathrm{T} 12$ & $6.57^{\mathrm{a}}$ & $50.42^{\mathrm{d}}$ & $64.58^{\mathrm{b}}$ & $164.18^{\mathrm{a}}$ & $100.63^{\mathrm{d}}$ & $134.58^{\mathrm{b}}$ \\
\hline $\mathrm{T} 13$ & $5.93^{\mathrm{a}}$ & $52.53^{\mathrm{c}, \mathrm{d}}$ & $19.37^{\mathrm{f}, \mathrm{h}}$ & $148.25^{\mathrm{a}}$ & $104.80^{\mathrm{c}, \mathrm{d}}$ & $89.38^{\mathrm{fhh}}$ \\
\hline T14 & $6.47^{\mathrm{a}}$ & $52.62^{\mathrm{c}, \mathrm{d}}$ & $10.36^{\mathrm{g}, \mathrm{j}}$ & $161.88^{\mathrm{a}}$ & $105.13^{\mathrm{c,d}}$ & $80.36^{\mathrm{g}, \mathrm{h}}$ \\
\hline T15 & $0.00^{\mathrm{c}}$ & $00.00^{\mathrm{g}}$ & $00.00^{j}$ & $00.00^{c}$ & $00.00^{\mathrm{g}}$ & $00.00^{\mathrm{i}}$ \\
\hline T16 & $6.63^{\mathrm{a}}$ & $105.22^{\mathrm{a}}$ & $328.51^{\mathrm{a}}$ & $165.83^{\mathrm{a}}$ & $209.44^{\mathrm{a}}$ & $299.50^{\mathrm{a}}$ \\
\hline LSD & 0.74 & 10.37 & 12.59 & 18.36 & 20.19 & 13.05 \\
\hline
\end{tabular}

T1: pretilachlor/safener fb bentazon/MCPA; T2: pretilachlor/safener fb manual weeding; T3: pretilachlor/safener fb propanil/thiobencarb; T4: pretilachlor/safener $\mathrm{fb}$ propanil/thiobencarb fb bentazon/MCPA; T5: pretilachlor/safener fb propanil/thiobencarb fb manual weeding; T6: propanil/thiobencarb; T7: propanil/thiobencarb fb bentazon/MCPA; T8: propanil/thiobencarb fb manual weeding; T9: cyhalofop-butyl + bensulfuron; T10: cyhalofop-butyl + bensulfuron fb bentazon/MCPA; T11: cyhalofop-butyl + bensulfuron fb manual weeding; T12: bispyribac-sodium; T13: bispyribac-sodium fb bentazon/MCPA; T14: bispyribac-sodium fb manual weeding; T15: season long weed-free by manual weeding; T16: season long weedy. LSD: least significant difference. Within a column, means sharing same alphabets are not significantly different at $P=0.05$ probability level according to the least significant difference (LSD) test.

manual weeding resulted in the highest WCE (97.93\%) identically followed by cyhalofop-butyl + bensulfuron $\mathrm{fb}$ manual weeding (97.60\%), bispyribac-sodium $\mathrm{fb}$ manual weeding (96.85\%), pretilachlor/safener fb propanil/thiobencarb $\mathrm{fb}$ bentazon/MCPA (96.45\%), and propanil/thiobencarb fb manual weeding (96.35\%) (Figure 1). Bispyribac-sodium, on the other hand, showed the lowest WCE (80.34\%) closely followed by propanil/thiobencarb (82.75\%), pretilachlor/safener $\mathrm{fb}$ bentazon/MCPA (83.90\%), and cyhalofop-butyl + bensulfuron $(85.16 \%)$. The present findings confirm that earlypostemergence application of any of the herbicides under study at $10 \mathrm{DAS}$ followed by manual weeding/postemergence application of Bentazon/MCPA at 30 DAS would result in excellent weed control.

3.5. Yield and Yield Attributes. Grain yield of AERON 1 varied significantly due to weed control treatments (Table 5). All the treatments resulted in significantly higher yield than weedy check did, and several treatments generated yield as high as weed-free yield. Pretilachlor/safener fb propanil/thiobencarb $\mathrm{fb}$ bentazon/MCPA or manual weeding, propanil/thiobencarb $\mathrm{fb}$ bentazon/MCPA or manual weeding, cyhalofop-butyl + bensulfuron fb bentazon/MCPA or manual weeding, and bispyribac-sodium $\mathrm{fb}$ manual weeding performed excellent in terms of yield (ranging from 4.40 to $4.55 \mathrm{t} / \mathrm{ha}$ ) which were statistically similar to that obtained from weed-free check $(4.68 \mathrm{t} / \mathrm{ha})$. pretilachlor/safener $\mathrm{fb}$ propanil/thiobencarb or $\mathrm{fb}$ bentazon/MCPA or manual weeding and bispyribac-sodium $\mathrm{fb}$ bentazon/MCPA also recorded acceptable yield ( $>4 \mathrm{t} / \mathrm{ha}$ ), very close to weed-free yield. Propanil/thiobencarb, cyhalofop-butyl + bensulfuron, and bispyribac-sodium, on the contrary, recorded comparatively lower yield (ranging between 3.66 and $3.77 \mathrm{t} / \mathrm{ha}$ ) but still much higher than weedy yield $(1.77 \mathrm{t} / \mathrm{ha})$. Yield attributes were significantly affected by herbicide treatments (Table 5). All the attributes attained their highest values in weed-free check and lowest values in the weedy check. In general, pretilachlor/safener $\mathrm{fb}$ propanil/thiobencarb $\mathrm{fb}$ bentazon/MCPA or manual weeding, propanil/thiobencarb $\mathrm{fb}$ bentazon/MCPA or manual weeding, cyhalofop-butyl + bensulfuron $\mathrm{fb}$ bentazon/MCPA or manual weeding, and bispyribac-sodium $\mathrm{fb}$ bentazon/MCPA or manual weeding performed best in terms of yield attributes. Single application of propanil/thiobencarb or cyhalofop-butyl + bensulfuron or bispyribac-sodium and application of propanil/thiobencarb $\mathrm{fb}$ bentazon/MCPA or manual weeding or propanil/thiobencarb resulted in the poorest yield attributes.

3.6. Relative Yield Loss. Relative yield loss due to weed varied widely (2.78-23.081\%) among the weed control treatments (Table 5). In weedy check, RYL was recorded as high as $62.18 \%$. Pretilachlor/safener fb propanil/thiobencarb fb manual weeding allowed the least yield penalty of only $2.78 \%$ closely followed by cyhalofop-butyl + bensulfuron $\mathrm{fb}$ manual 
TABLE 5: Yield attributes, yield and relative yield loss of rice variety AERON 1 as influenced by weed control treatments (averaged over seasons).

\begin{tabular}{|c|c|c|c|c|c|}
\hline Treatment & $\begin{array}{l}\text { Panicles/ } \\
\mathrm{m}^{2} \text { (no.) }\end{array}$ & $\begin{array}{l}\text { Filled grains/ } \\
\text { panicle (no.) }\end{array}$ & Thousand-seed weight (g) & Grain yield (t/ha) & Relative yield loss (\%) \\
\hline $\mathrm{T} 1$ & $236.00^{\mathrm{e}}$ & $57.83^{\mathrm{e}, \mathrm{f}}$ & $26.23^{\mathrm{e}}$ & $4.05^{\mathrm{e}}$ & 13.46 \\
\hline $\mathrm{T} 2$ & $235.17^{\mathrm{e}}$ & $59.00^{\mathrm{d}, \mathrm{e}}$ & $26.28^{\mathrm{e}}$ & $4.13 \mathrm{~d}^{\mathrm{e}}$ & 11.75 \\
\hline T3 & $244.00^{\mathrm{d}, \mathrm{e}}$ & $59.67^{\mathrm{c}, \mathrm{e}}$ & $26.90^{\mathrm{d}}$ & $4.23^{\mathrm{c}, \mathrm{e}}$ & 9.62 \\
\hline $\mathrm{T} 4$ & $270.83^{\mathrm{a}}$ & $63.90^{\mathrm{a}, \mathrm{b}}$ & $27.33^{\mathrm{b}, \mathrm{c}}$ & $4.49^{\mathrm{a}, \mathrm{c}}$ & 4.06 \\
\hline $\mathrm{T} 5$ & $273.50^{\mathrm{a}}$ & $63.83^{\mathrm{a}, \mathrm{b}}$ & $27.40^{\mathrm{a}, \mathrm{b}}$ & $4.55^{\mathrm{a}, \mathrm{b}}$ & 2.78 \\
\hline T6 & $220.83^{f}$ & $54.17^{\mathrm{f}, \mathrm{g}}$ & $26.05^{\mathrm{e}}$ & $3.67^{\mathrm{f}}$ & 21.58 \\
\hline $\mathrm{T} 7$ & $254.67^{\mathrm{c}, \mathrm{d}}$ & $63.17^{\mathrm{a}, \mathrm{c}}$ & $27.27^{b, c}$ & $4.40^{\mathrm{a}, \mathrm{d}}$ & 5.98 \\
\hline $\mathrm{T} 8$ & $258.00^{\mathrm{b}, \mathrm{c}}$ & $62.17^{\mathrm{a}, \mathrm{d}}$ & $27.33^{\mathrm{b}, \mathrm{c}}$ & $4.43^{\mathrm{a}, \mathrm{c}}$ & 5.34 \\
\hline T9 & $220.50^{\mathrm{f}}$ & $51.33^{\mathrm{g}}$ & $26.27^{\mathrm{e}}$ & $3.77^{\mathrm{f}}$ & 20.44 \\
\hline $\mathrm{T} 10$ & $268.50^{\mathrm{a}, \mathrm{b}}$ & $64.12^{\mathrm{a}, \mathrm{b}}$ & $27.32^{\mathrm{b}, \mathrm{c}}$ & $4.47^{\mathrm{a}, \mathrm{c}}$ & 4.49 \\
\hline T11 & $273.00^{\mathrm{a}}$ & $64.33^{\mathrm{a}, \mathrm{b}}$ & $27.50^{\mathrm{a}, \mathrm{b}}$ & $4.53^{\mathrm{a}, \mathrm{b}}$ & 3.21 \\
\hline $\mathrm{T} 12$ & $215.83^{\mathrm{f}}$ & $53.83^{\mathrm{f}, \mathrm{g}}$ & $26.27^{\mathrm{e}}$ & $3.60^{\mathrm{f}}$ & 23.08 \\
\hline $\mathrm{T} 13$ & $244.17^{\mathrm{d}, \mathrm{e}}$ & $61.33^{\mathrm{b}, \mathrm{e}}$ & $26.90^{\mathrm{d}}$ & $4.36^{\mathrm{b}, \mathrm{d}}$ & 6.84 \\
\hline $\mathrm{T} 14$ & $271.17^{\mathrm{a}}$ & $64.50^{\mathrm{a}, \mathrm{b}}$ & $27.32^{\mathrm{b}, \mathrm{c}}$ & $4.45^{\mathrm{a}, \mathrm{c}}$ & 4.91 \\
\hline $\mathrm{T} 15$ & $275.33^{\mathrm{a}}$ & $66.00^{\mathrm{a}}$ & $27.62^{\mathrm{a}}$ & $4.68^{\mathrm{a}}$ & 00.00 \\
\hline T16 & $180.43^{\mathrm{g}}$ & $45.83^{\mathrm{h}}$ & $25.53^{\mathrm{f}}$ & $1.77^{\mathrm{g}}$ & 62.18 \\
\hline LSD & 10.98 & 4.04 & 0.26 & 0.28 & - \\
\hline
\end{tabular}

T1: pretilachlor/safener fb bentazon/MCPA; T2: pretilachlor/safener $\mathrm{fb}$ manual weeding; T3: pretilachlor/safener fb propanil/thiobencarb; T4: pretilachlor/safener fb propanil/thiobencarb fb bentazon/MCPA; T5: pretilachlor/safener fb propanil/thiobencarb fb manual weeding; T6: propanil/thiobencarb; T7: propanil/thiobencarb fb bentazon/MCPA; T8: propanil/thiobencarb fb manual weeding; T9: cyhalofop-butyl + bensulfuron; T10: cyhalofop-butyl + bensulfuron fb bentazon/MCPA; T11: cyhalofop-butyl + bensulfuron $\mathrm{fb}$ manual weeding; T12: bispyribac-sodium; T13: bispyribac-sodium fb bentazon/MCPA; T14: bispyribac-sodium fb manual weeding; T15: season long weed-free by manual weeding; T16: season long weedy. LSD: least significant difference. Within a column, means sharing same alphabets are not significantly different at $P=0.05$ probability level according to the least significant difference (LSD) test.

weeding $(3.21 \%)$, pretilachlor/safener $\mathrm{fb}$ propanil/thiobencarb fb bentazon/MCPA (4.06\%), cyhalofop-butyl + bensulfuron $\mathrm{fb}$ bentazon/MCPA (4.49\%), and bispyribac-sodium $\mathrm{fb}$ manual weeding (4.91\%). A single application of bispyribacsodium or propanil/thiobencarb or cyhalofop-butyl + bensulfuron resulted in high RYL $(>20 \%)$. The remaining treatments allowed moderate RYL ranging between 6 and 13\%.

3.7. Economics. Weed control treatments showed a wide range of economic return (Table 6). Cost analysis revealed that the highest net benefit of Ringgit Malaysia (RM) 4086/ha was recorded with cyhalofop-butyl + bensulfuron fb bentazon/MCPA closely followed by bispyribac-sodium $\mathrm{fb}$ bentazon/MCPA (RM 4080/ha), propanil/thiobencarb fb bentazon/MCPA (RM 3988/ha), and pretilachlor/safener $\mathrm{fb}$ propanil/thiobencarb fb bentazon/MCPA (RM 3911/ha). Pretilachlor/safener $\mathrm{fb}$ bentazon/MCPA and pretilachlor/ safener $\mathrm{fb}$ propanil/thiobencarb also resulted in high net benefit (RM 3773/ha and RM 3761/ha, resp.). A single earlypostemergence spray with propanil/thiobencarb or bispyribac-sodium or cyhalofop-butyl + bensulfuron recorded moderate net benefit ranging from RM 3368/ha to RM 3496/ha. On the other hand, when manual weeding was integrated with herbicides, net benefits were found lower (ranging from RM 2713/ha to RM 3030/ha) as compared with those obtained from only herbicide application. The season-long weed-free plots resulted in a net benefit of only RM 2180/ha which was not much higher than that obtained from season-long weedy plots (RM 1770/ha), and comparatively lower than that of any of the treatments. Despite the highest gross income (RM 4680/ha), season-long weed-free plots resulted in very low net benefit because of high cost involvement in manual weeding (RM 2500/ha). The results further revealed that in every case when bentazon/MCPA was replaced by manual weeding, gross income was increased marginally but net benefit was reduced considerably because of much higher cost involvement in manual weeding (RM 1250/ha) compared to Bentazon/MCPA (RM 110/ha). Thus, integrated weed management resulted in lower economic return compared to herbicide based management.

\section{Discussion}

The existence and risk of developing herbicide resistance and concern about herbicidal impact on environment and public health make herbicide dominated weed management increasingly vulnerable. To reduce herbicide reliance, one approach is to adjust crop management practices such that crop-weed interactions are altered to the benefit of the crop [15], but this is not enough to manage weeds. Till now herbicide is a cost effective tool to fight against weeds, and therefore, weed management system using herbicides probably will continue. 
TABLE 6: Cost effectiveness of different herbicide treatments (averaged over seasons).

\begin{tabular}{|c|c|c|c|c|c|}
\hline Ttreatment & $\begin{array}{l}\text { Herbicide cost } \\
(\mathrm{RM} / \mathrm{ha})\end{array}$ & $\begin{array}{l}\text { Laborer cost for spraying/ } \\
\text { weeding (RM/ha) }\end{array}$ & $\begin{array}{l}\text { Total cost } \\
(\mathrm{RM} / \mathrm{ha})\end{array}$ & $\begin{array}{c}\text { Gross income } \\
(\mathrm{RM} / \mathrm{ha})\end{array}$ & $\begin{array}{c}\text { Net benefit } \\
(\mathrm{RM} / \mathrm{ha})\end{array}$ \\
\hline $\mathrm{T} 1$ & $117+60$ & $50+50$ & 277 & 4050 & 3773 \\
\hline $\mathrm{T} 2$ & 117 & $50+1250$ & 1417 & 4130 & 2713 \\
\hline T3 & $117+252$ & $50+50$ & 469 & 4230 & 3761 \\
\hline $\mathrm{T} 4$ & $117+252+60$ & $50+50+50$ & 579 & 4490 & 3911 \\
\hline T5 & $117+252$ & $50+50+1250$ & 1719 & 4550 & 2831 \\
\hline T6 & 252 & 50 & 302 & 3670 & 3368 \\
\hline $\mathrm{T} 7$ & $252+60$ & $50+50$ & 412 & 4400 & 3988 \\
\hline $\mathrm{T} 8$ & 252 & $50+1250$ & 1552 & 4430 & 2878 \\
\hline T9 & $110+114$ & 50 & 274 & 3770 & 3496 \\
\hline $\mathrm{T} 10$ & $110+114+60$ & $50+50$ & 384 & 4470 & 4086 \\
\hline T11 & $110+114$ & $50+1250$ & 1524 & 4530 & 3006 \\
\hline $\mathrm{T} 12$ & 120 & 50 & 170 & 3600 & 3430 \\
\hline $\mathrm{T} 13$ & $120+60$ & $50+50$ & 280 & 4360 & 4080 \\
\hline $\mathrm{T} 14$ & 120 & $50+1250$ & 1420 & 4450 & 3030 \\
\hline $\mathrm{T} 15$ & 0.0 & 2500 & 2500 & 4680 & 2180 \\
\hline T16 & 0.0 & 0.0 & 0.0 & 1770 & 1770 \\
\hline
\end{tabular}

T1: pretilachlor/safener fb bentazon/MCPA; T2: pretilachlor/safener fb manual weeding; T3: pretilachlor/safener fb propanil/thiobencarb; T4: pretilachlor/safener $\mathrm{fb}$ propanil/thiobencarb fb bentazon/MCPA; T5: pretilachlor/safener fb propanil/thiobencarb fb manual weeding; T6: propanil/thiobencarb; T7: propanil/thiobencarb fb bentazon/MCPA; T8: propanil/thiobencarb fb manual weeding; T9: cyhalofop-butyl + bensulfuron; T10: cyhalofop-butyl + bensulfuron fb bentazon/MCPA; T11: cyhalofop-butyl + bensulfuron fb manual weeding; T12: bispyribac-sodium; T13: bispyribac-sodium fb bentazon/MCPA; T14: bispyribac-sodium fb manual weeding; T15: season long weed-free by Manual weeding; T16: season long weedy.

RM: Ringgit Malaysia. Market price of herbicide commercial products: pretilachlor/safener (Soffit N300 EC) = 70 RM/L, cyhalofop-butyl (Halop 100 EC) $=110 \mathrm{RM} / \mathrm{L}$, bensulfuron $($ Tekong) $=19 \mathrm{RM} \mathrm{100/g}$, bispyribac-sodium (Nominee $100 \mathrm{SC})=98 \mathrm{RM} 250 / \mathrm{mL}$, propanil/thiobencarb $($ Satuni) $=42 \mathrm{RM} / \mathrm{L}$, and bentazon/MCPA (basagran M60) $=38 \mathrm{RM} / \mathrm{L}$.

Manual weeding cost: 100 laborers/ha for 2 weedings at $25 \mathrm{RM} /$ laborer/day, herbicide application cost: 2/laborer/ha/round at $25 \mathrm{RM} /$ laborer/day, market price of paddy: $1000.00 \mathrm{RM} t / \mathrm{ha}$, gross income = paddy yield $(\mathrm{t} / \mathrm{ha}) \times$ market price $(\mathrm{RM} \mathrm{t} / \mathrm{ha})$, and net benefit $=$ gross income - total weeding cost.

1 US\$ = 3 RM (approx.).

The present study advocates an integrated approach of weed management for aerobic rice with a reduced reliance on herbicides.

Naturally occurring weed flora of the study area represented 19 weed species belonging to 11 families. Broadleaf was the most dominant group followed by sedges and grasses. Weed community in the aerobic rice is generally dominated by broadleaf weeds followed by sedges and grasses [18, 33]. Anwar et al. [24] also reported that the relative composition of the broadleaf, sedges, and grasses were about $60 \%, 20 \%$, and $20 \%$, respectively, in aerobic rice field, and the most dominant weed species were $P$. heterophylla Nees, S. dulcis, C. rutidosperma, and C. rotundus. In contrast, Jaya Suria et al. [34] accounted from their trial with aerobic rice that grassy weeds constituted about $80 \%$ of total weed community. Greater abundance of broadleaf weeds under saturated conditions and dominance of sedges, and grasses under dry seeded/aerobic conditions have also been documented by Moody and Drost [35]. The differences in the weed composition might be due to variation in agroecological conditions, management practices, and weed seed bank composition among the study areas.

Across the seasons, weed dry weight and density in the weedy check were recorded as $328 \mathrm{~g} / \mathrm{m}^{2}$ and $299 / \mathrm{m}^{2}$, respectively. The high weed pressure under aerobic soil conditions as observed in this study is long established as reported by many researchers [24, 25, 33, 36, 37]. Dry tillage coupled with aerobic soil conditions [6], lack of a "head start" of rice seeds over germinating weed seeds [38], and absence of flooding to suppress the initial flush of weeds [39] are the plausible causes behind the high weed invasion in aerobic rice. As De Datta and Baltazar [40] stated, rice ecosystem and management practices mostly determine weed pressure, riceweed competition, and ultimately the weed control tactics. Therefore, understanding the weed community in terms of species dominance pattern and pressure is necessary for successful weed management. The weed density and dry weight recorded in this study are, respectively, 36 and $14 \%$ lower than those obtained from herbicide screening trial [24] and 39 and 20\% lower than those observed in critical period study [26]. All the three studies were conducted with rice germplsm AERON 1 in the same seasons at the same site and set of agroclimatic conditions. Despite the likeness in spatiotemporal aspects among those three studies, much lower weed pressure in the present study as compared to those of previous studies might be the contribution of integrating higher seed rate $\left(300\right.$ instead of 200 seeds $\left./ \mathrm{m}^{2}\right)$ and seed invigoration (Zappa primed seeds instead of unprimed ones). 
Sowing primed seeds at a higher rate enhanced the competitiveness of rice against weeds which eventually reduced weed density and dry weight.

In this study, 14 different combinations of six commercial herbicide products were integrated with manual weeding aimed at controlling weeds during the predetermined critical period of weed competition of 20-43 days after seeding [26]. Every herbicide formulation was found effective in arresting weed growth. All the weed control treatments showed high weed control efficiency ( $>80 \% \mathrm{WCE}$ ), and a number of them provided excellent weed control ( $>95 \%$ WCE). Preemergence application $\mathrm{fb}$ early-postemergence application $\mathrm{fb}$ postemergence application or manual weeding and earlypostemergence application $\mathrm{fb}$ postemergence application or manual weeding resulted in higher WCE as compared with a single early-postemergence application. This might be due to that late emerged weeds remained uncontrolled when preemergence or early-postemergence application was not followed by a spraying with postemergence herbicide or manual weeding at midgrowth stages of rice to cover the entire critical period of weed competition. These results are in line with that of Sunil et al. [33], who opined that for achieving high WCE in aerobic rice a preemergence application must be followed by a manual weeding at 40 DAS. Highest WCE in aerobic rice variety AERON 1 resulted from earlypostemergence application at $10 \mathrm{DAS}$ followed by a manual weeding at 43 DAS has also been reported by Jaya Suria et al. [34]. The WCEs obtained from this study (ranging from 80 to $98 \%$ ) are comparatively higher than those recorded with the previous study (ranging from 53 to $92 \%$ ) conducted at the same site considering same herbicides [24]. Combined merits of higher seeding rate and seed priming provided a more competitive cropping system in favor of rice in the present study compared to the previous one, which might enhance herbicide efficacy. Earlier studies have similarly documented that improved agronomic practices can effectively suppress weed growth and increase herbicide efficacy $[1,41]$.

None of the herbicides under study caused any significant injury to rice plant, and thus, they exhibited high selectivity to rice. Minor injuries were evident with few herbicides which disappeared shortly. At the late season evaluation, no injury was visible from any herbicide treatment. As observed in the earlier study [24], bentazon/MCPA applied at 40 DAS exhibited no injury to rice plant at $7 \mathrm{DAA}$, while in the present study, when applied at 30 DAS to match with the critical period of weed competition, bentazon/MCPA caused slight phytotoxicity to rice at $7 \mathrm{DAA}$. A possible explanation for this might be that rice plant is susceptible to bentazon/MCPA if applied before 40 DAS. No phytotoxicity was observed in AERON 1 due to bentazon/MCPA application at 43 DAS [34]. Thus, herbicide phytotoxicity is crop growth stage specific as confirmed by Levene and Owen [42]. Herbicides in this study were applied following manufacturers' recommendations, which might result in no/very slight injury to rice plants. Moreover, aerobic soil conditions helped reduce herbicide injury to the crop [43]. In fact, rice plant shows high tolerance to herbicides and may suffer slight initial injuries which disappear shortly, but seldom phytotoxicity persists up to crop harvest [43].
Weed control efficiency (WCE) was eventually translated into grain yield. All the weed control treatments significantly out-yielded weedy check, and some performed as good as weed-free check because of their high WCE. In contrast, weed control treatments with low WCE resulted in reduced yield. The WCE is also reflected in RYL. As evident from this study, the higher the WCE the lower the RYL. The increase in rice grain yield by increasing WCE has also been reported by others $[24,34]$. Reasonably, weedy check allowed the maximum RYL. In fact, weed removal reduces interspecific competition for resources and enables crop to utilize available resources more efficiently than weeds which eventually results in higher yield. Early-postemergence application at 10 DAS followed by postemergence application or manual weeding at $30 \mathrm{DAS}$ resulted in similar grain yield with season long weed-free or preemergence application at 1 DAS followed by early-postemergence application at 10 DAS followed by postemergence application or manual weeding at 30 DAS. On the other hand, a single early-postemergence application at 10 DAS not followed by a postemergence application or manual weeding at 30 DAS resulted in considerable yield reduction compared to weed-free check. This finding justifies the implication of critical period of weed competition and confirms that presence of weeds before or after critical period of weed competition (20-43 DAS for this study) will not pose a threat to crop yield, and yield obtained by keeping weed-free during CPWC is almost similar to that obtained by keeping weed-free throughout [26]. Also, both weedy and weed-free yields were recorded higher and RYL against different weed control treatments were recorded lower in the present study as compared to the earlier study [24]. This result may be explained by the fact that the use of primed seed coupled with higher seed rate in the present study resulted in faster and higher emergence rate along with vigorous stand offering rice plants an advantage to tolerate and outcompete weeds, which is ultimately translated into higher yield. It is encouraging to compare this finding with that of Blackshaw et al. [1] who confirmed that integration of agronomic practices like seeding rate and seeding time in conjunction with limited herbicide use could increase crop yield and reduce weed pressure.

In the present study, all the yield attributes responded significantly to weed control treatments. These findings are in agreement with those of Sunil et al. [33], who observed that all the yield attributes of aerobic rice were significantly influenced by weed control treatments. In contrast, Juraimi et al. [44] found that only number of panicle $/ \mathrm{m}^{2}$ was influenced by weed control treatments. Thus, responses of yield components of rice to herbicide treatments are variable.

The economics of a weed control method is determined by its cost involvement and WCE. Similarly as Wibawa et al. [45] stated, the economics of herbicide depends on the price, recommended dosage, and efficacy. In this study, cost of different weed control treatments varied widely. Treatments comprising only herbicides required low cost involvement and thus produced higher net benefit, on the contrary, treatments comprising both herbicide and manual weeding required high cost involvement and resulted in lower net benefit. In season-long weed-free check, despite the maximum 


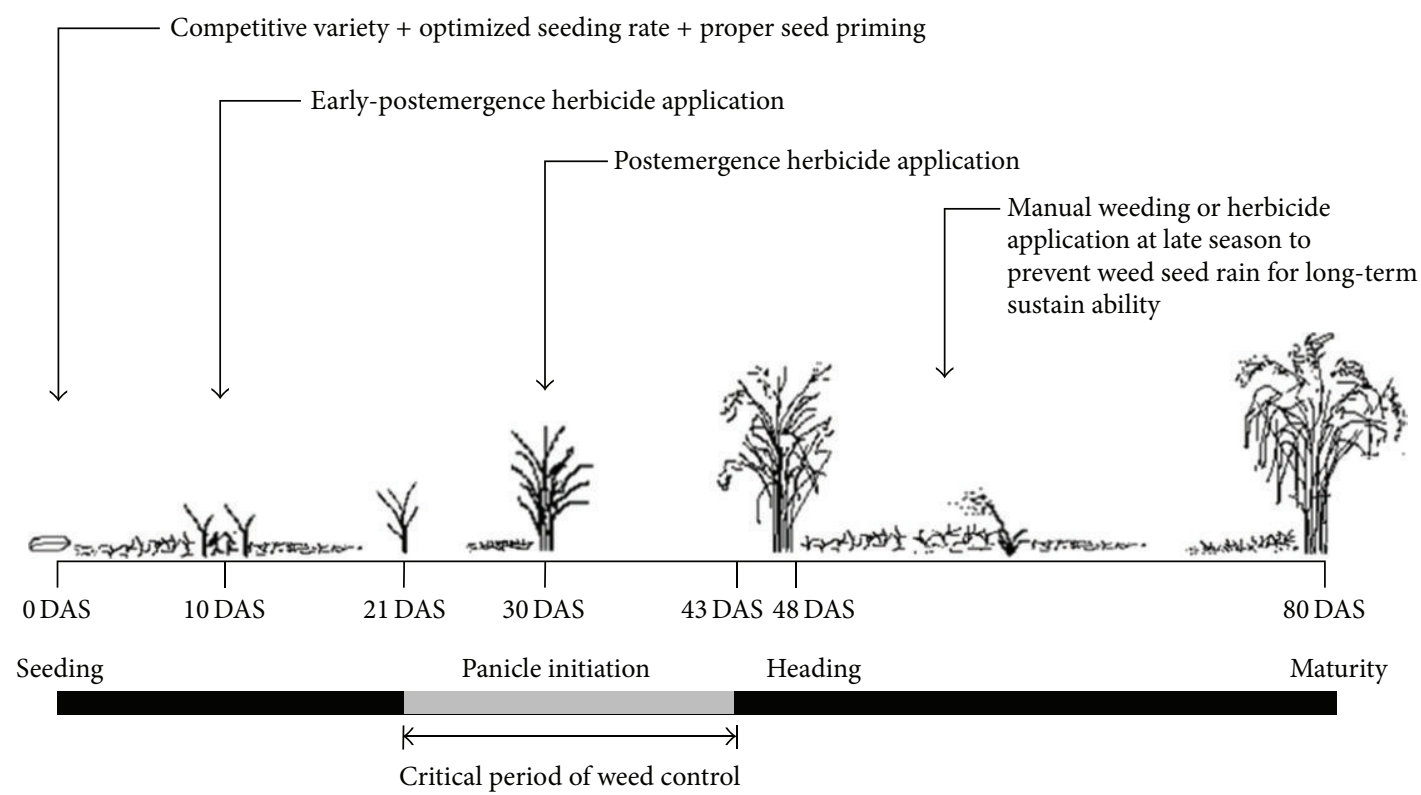

DAS Days after seeding

Must be kept weed-free to prevent economic yield loss

No significant impact of weeding on yield

FIGURE 2: Integrated weed management schedule for aerobic rice production.

gross income (RM 4680/ha), net benefit was much lower (RM $2180 /$ ha) and very close to that of weedy check (RM 1770/ha). Season-long weed-free check generated an additional return of only RM 410/ha over season-long weedy checks. When bentazon/MCPA was replaced by manual weeding, gross income increased but net benefit decreased because of high cost involvement in manual weeding. Even a single earlypostemergence application generated more net benefit as compared to early-postemergence application followed by manual weeding. Consequently, manual weeding is less remunerative compared to herbicidal control, and practicing manual weeding throughout the season is a losing concern, confirming the view of many others [31, 33, 37]. Compared to earlier study [24], higher gross income and higher net benefit were encountered in the present study, which might be due to better yield and higher WCE as a consequence of more competitive cropping system in favor of rice.

\section{Conclusions}

A more competitive cropping system in favor of rice as a consequence of combined use of competitive variety, higher seeding rate, and seed priming is evident from the study, which was reflected in lower weed pressure, higher weed control efficiency, and better yield. Weed control only during critical period of competition is also justified as some weed control treatments produced yield similar to weed-free yield. Herbicide and manual weeding combinations resulted in lower net benefit compared to herbicidal control because of high cost involvement in manual weeding. From economic view points, application of cyhalofop-butyl + bensulfuron or bispyribac-sodium or propanil/thiobencarb at 10 DAS followed by bentazon/MCPA at 30 DAS can be recommended, while for the sustainability of long-term weed management, cyhalofop-butyl + bensulfuron or bispyribac-sodium or propanil/thiobencarb should be applied in rotation at 10 DAS followed by a manual weeding at 30 DAS. Based on the findings of this study, an integrated weed management schedule for aerobic rice has been presented in Figure 2.

\section{Acknowledgments}

The authors sincerely acknowledge UPM Research University Grant (01-04-08-0543RU) and Long term Research Grant Scheme (LRGS), Food Security Project, Ministry of Higher Education, Malaysia, for providing financial support of the project.

\section{References}

[1] R. E. Blackshaw, J. R. Moyer, K. N. Harker, and G. W. Clayton, "Integration of agronomic practices and herbicides for sustainable weed management in a zero-till barley field pea rotation," Weed Technology, vol. 19, no. 1, pp. 190-196, 2005.

[2] D. D. Buhler, "Challenges and opportunities for integrated weed management," Weed Science, vol. 50, no. 3, pp. 273-280, 2002.

[3] D. D. Buhler, M. Liebman, and J. J. Obrycki, "Theoretical and practical challenges to an IPM approach to weed management," Weed Science, vol. 48, no. 3, pp. 274-280, 2000.

[4] N. H. Spliid and B. Køppen, "Occurrence of pesticides in Danish shallow ground water," Chemosphere, vol. 37, no. 7, pp. 1307-1316, 1998. 
[5] E. J. P. Marshall, V. K. Brown, N. D. Boatman, P. J. W. Lutman, G. R. Squire, and L. K. Ward, "The role of weeds in supporting biological diversity within crop fields," Weed Research, vol. 43, no. 2, pp. 77-89, 2003.

[6] V. Balasubramanian and J. E. Hill, "Direct seeding of rice in Asia: emerging issues and strategic research needs for the 21st century," in Direct Seeding: Research Strategies and Opportunities, S. Pandey and International Rice Research Institute, Eds., pp. 15-39, IRRI, Los Banos, Philippines, 2002.

[7] M. Begum, A. S. Juraimi, R. Amartalingum, S. R. S. Omar, and A. B. Man, "Effect of Fimbristylis miliacea competition with MR220 rice in relation to different nitrogen levels and weed density," International Journal of Agriculture and Biology, vol. 11, no. 2, pp. 183-187, 2009.

[8] A. S. Juraimi, M. K. Uddin, M. P. Anwar, M. T. M. Mohamed, M. R. Ismail, and A. Man, "Sustainable weed management in direct seeded rice culture: a review," Australian Journal of Crop Science, vol. 7, pp. 989-1002, 2013.

[9] K. Jabran, M. Farooq, M. Hussain et al., "Efficient weeds control with penoxsulam application ensures higher productivity and economic return of direct seeded rice," International Journal of Agriculture and Biology, vol. 14, pp. 901-907, 2012.

[10] G. A. Buchanan, "Management of the weed pests of cotton (Gossypium hirsutum)," in Proceedings, U.S.-U.S.S.R. Symposium: The Integrated Control of the Arthropod, Disease and Weed Pests of Cotton, Grain Sorghum and Deciduous Fruit, pp. 168184, Lubbock, Tex, USA, October 1975.

[11] D. C. Thill, J. M. Lish, R. H. Callihan, and E. J. Bechinski, "Integrated weed management-a component of integrated pest management: a critical review," Weed Technology, vol. 5, pp. 648-656, 1991.

[12] D. L. Wyse, "Future of weed science research," Weed Technology, vol. 6, pp. 162-165, 1992

[13] C. L. Elmore, "A reintroduction to integrated weed management," Weed Science, vol. 44, no. 2, pp. 409-412, 1996.

[14] C. J. Swanton and S. F. Weise, "Integrated weed management: the rationale and approach," Weed Technology, vol. 5, pp. 657663, 1991.

[15] L. Bastiaans, M. J. Kropff, J. Goudriaan, and H. H. van Laar, "Design of weed management systems with a reduced reliance on herbicides poses new challenges and prerequisites for modeling crop-weed interactions," Field Crops Research, vol. 67, no. 2, pp. 161-179, 2000.

[16] K. Mahmood, M. B. Khan, M. Hussain, and M. A. Gorchani, "Weed management in wheat field (Triticum aestivum) using allelopathic crop water extracts," International Journal of Agriculture and Biology, vol. 11, no. 6, pp. 751-755, 2009.

[17] M. Azmi and B. B. Baki, "Impact of continuous direct seeding rice culture on weed species diversity in the Malaysian rice ecosystem," in Proceedings of the Regional Symposium on Environment and Natural Resources, vol. 1, pp. 61-67, Kuala Lumpur, Malaysia, April 2002.

[18] H. M. Jayadeva, S. T. Bhairappanavar, A. Y. Hugar et al., "Integrated weed management in aerobic rice (Oryza sativa L.)," Agriculture Science Digest, vol. 31, pp. 58-61, 2011.

[19] B. Melander, I. A. Rasmussen, and P. Bàrberi, "Integrating physical and cultural methods of weed control-examples from European research," Weed Science, vol. 53, no. 3, pp. 369-381, 2005.

[20] D. L. Zhao, G. N. Atlin, L. Bastiaans, and J. H. J. Spiertz, "Comparing rice germplasm groups for growth, grain yield and weed-suppressive ability under aerobic soil conditions," Weed Research, vol. 46, no. 6, pp. 444-452, 2006.

[21] P. Anwar, A. S. Juraimi, A. Man, A. Puteh, A. Selamat, and M. Begum, "Weed suppressive ability of rice (Oryza sativa L.) germplasm under aerobic soil conditions," Australian Journal of Crop Science, vol. 4, no. 9, pp. 706-717, 2010.

[22] P. Anwar, A. S. Juraimi, A. Puteh, A. Selamat, A. Man, and A. Hakim, "Seeding method and rate influence on weed suppression in aerobic rice," African Journal of Biotechnology, vol. 10, no. 68, pp. 15259-15271, 2011.

[23] A. S. M. Jaya Suria, A. S. Juraimi, A. Man, M. P. Anwar, and M. K. Uddin, "Critical period of weed control in aerobic rice system," Australian Journal of Crop Science, vol. 7, no. 5, pp. 665673, 2013.

[24] M. P. Anwar, A. S. Juraimi, A. Puteh, A. Man, and M. M. Rahman, "Efficacy, phytotoxicity and economics of different herbicides in aerobic rice," Acta Agriculturae Scandinavica B, vol. 62, no. 7, pp. 604-615, 2012.

[25] M. P. Anwar, A. S. Juraimi, A. Puteh, A. Selamat, M. M. Rahman, and M. Samedani, "Seed priming influences weed competitiveness and productivity of aerobic rice," Acta Agriculturae Scandinavica B, vol. 62, no. 6, pp. 499-509, 2012.

[26] M. P. Anwar, A. S. Juraimi, B. Samedani, A. Puteh, and A. Man, "Critical period of weed control in aerobic rice," The Scientific World Journal, vol. 2012, Article ID 603043, 10 pages, 2012.

[27] Malaysian Agriculture Research and Development Institute, Manual Penanaman Padi Berhasil Tinggi, Institut Penyelidikan dan Kemajuan Pertanian Malaysia, Serdang, Malaysia, 1st edition, 2002.

[28] J. D. Janiya and K. Moody, "Weed populations in transplanted wet-seeded rice as affected by weed control method," Tropical Pest Management, vol. 35, no. 1, pp. 8-11, 1989.

[29] L. I. Okafor, "Predominant weeds in Nigeria," Tropical Pest Management, vol. 32, no. 4, pp. 261-266, 1986.

[30] M. Hasanuzzaman, M. O. Islam, and M. S. Bapari, "Efficacy of different herbicides over manual weeding in controlling weeds in transplanted rice," Australian Journal of Crop Science, vol. 2, pp. 18-24, 2008.

[31] S. Hussain, M. Ramzan, M. Akhter, and M. Aslam, "Weed management in direct seeded rice," Journal of Animal and Plant Science, vol. 18, pp. 86-88, 2008.

[32] Statistical Analysis System, The SAS System for Windows, Version 9. 1, SAS Institute, Cary, NC, USA, 2003.

[33] C. M. Sunil, B. G. Shekara, K. N. Kalyanmurth, and B. C. Shankaralingapa, "Growth and yield of aerobic rice as influenced by integrated weed management practices," Indian Journal of Weed Science, vol. 42, pp. 180-183, 2010.

[34] A. S. M. Jaya Suria, A. S. Juraimi, M. M. Rahman, A. B. Man, and A. Selamat, "Efficacy and economics of different herbicides in aerobic rice system," African Journal of Biotechnology, vol. 10, no. 41, pp. 8007-8022, 2011.

[35] K. Moody and D. C. Drost, "The role of cropping systems on weed in rice," in Weed Control in Rice, pp. 74-88, International Rice Research Institute, Los Banos, Philippines, 1983.

[36] A. N. Rao, D. E. Johnson, B. Sivaprasad, J. K. Ladha, and A. M. Mortimer, "Weed management in direct-seeded rice," Advances in Agronomy, vol. 93, pp. 153-255, 2007.

[37] G. Mahajan, B. S. Chauhan, and D. E. Johnson, "Weed management in aerobic rice in northwestern indo-gangetic plains," Journal of Crop Improvement, vol. 23, no. 4, pp. 366-382, 2009. 
[38] D. L. Zhao, G. N. Atlin, L. Bastiaans, and J. H. J. Spiertz, "Developing selection protocols for weed competitiveness in aerobic rice," Field Crops Research, vol. 97, no. 2-3, pp. 272-285, 2006.

[39] M. Olofsdotter, B. E. Valverde, and K. H. Madsen, "Herbicide resistant rice (Oryza sativa L.): global implications for weedy rice and weed management," Annals of Applied Biology, vol. 137, no. 3, pp. 279-295, 2000.

[40] S. K. de Datta and A. M. Baltazar, "Weed control technology as a component of rice production systems," in Weed Management in Rice, B. A. Auld and K. U. Kim, Eds., Paper 139, pp. 27-52, FAO Plant Production and Protection, Rome, Italy, 1996.

[41] J. T. O’Donovan, K. N. Harker, G. W. Clayton, J. C. Newman, D. Robinson, and L. M. Hall, "Barley seeding rate influences the effects of variable herbicide rates on wild oat," Weed Science, vol. 49, no. 6, pp. 746-754, 2001.

[42] B. C. Levene and M. D. Owen, "Effect of moisture stress and leaf age on bentazon absorption in common cocklebur (Xanthium strumarium) and velvetleaf (Abutilon theophrasti)," Weed Science, vol. 43, no. 1, pp. 7-12, 1995.

[43] B. S. Chauhan and D. E. Johnson, "Growth response of directseeded rice to oxadiazon and bispyribac-sodium in aerobic and saturated soils," Weed Science, vol. 59, no. 1, pp. 119-122, 2011.

[44] A. S. Juraimi, M. Begum, M. N. M. Yusof, and A. Man, "Efficacy of herbicides on the control weeds and productivity of direct seeded rice under minimal water conditions," Plant Protection Quarterly, vol. 25, no. 1, pp. 19-25, 2010.

[45] W. Wibawa, M. G. Mohayidin, R. B. Mohamad, A. S. Juraimi, and D. Omar, "Efficacy and cost-effectiveness of three broadspectrum herbicides to control weeds in immature oil palm plantation," Pertanika Journal of Tropical Agricultural Science, vol. 33, no. 2, pp. 233-241, 2010. 


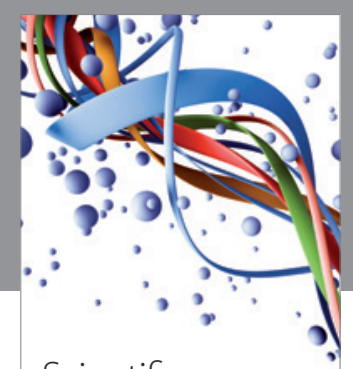

Scientifica
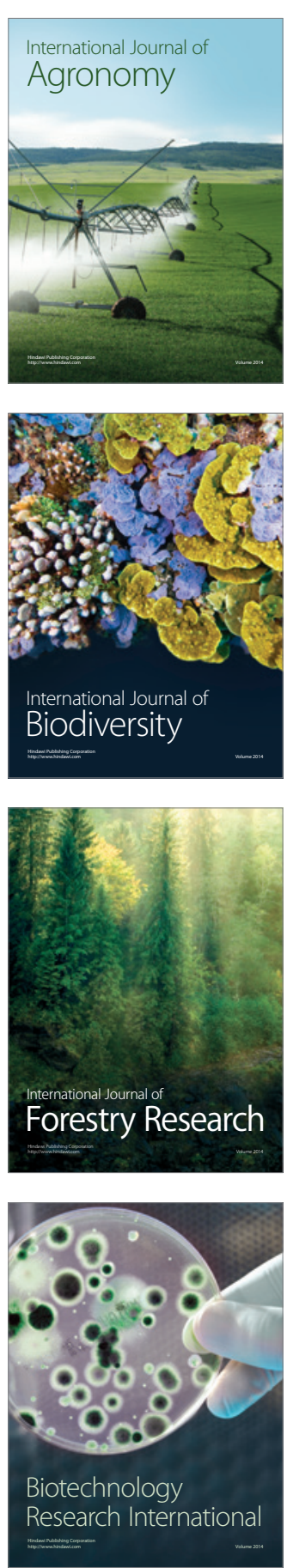
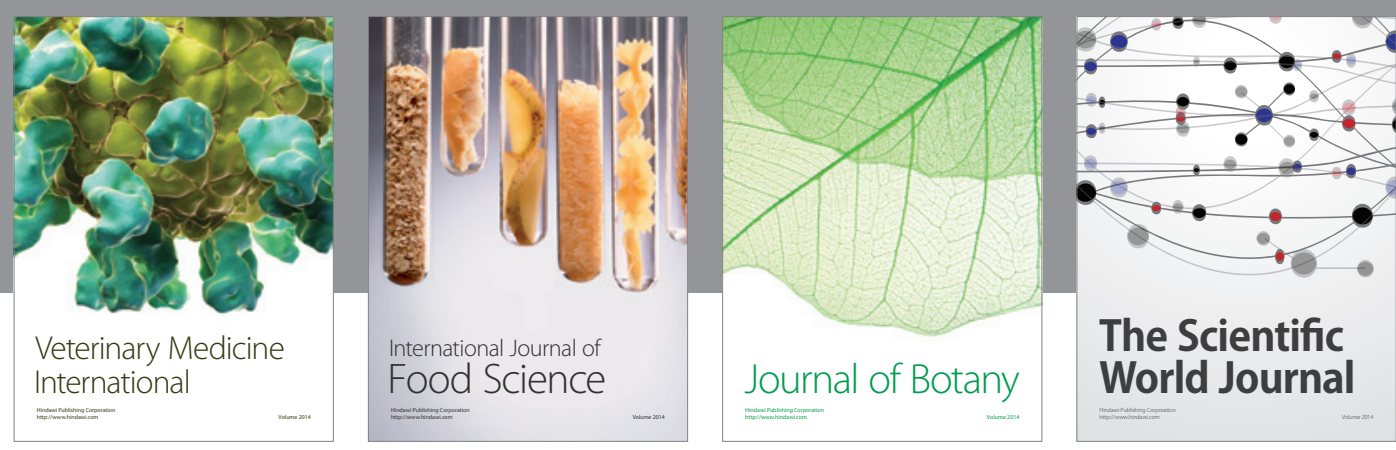

The Scientific World Journal
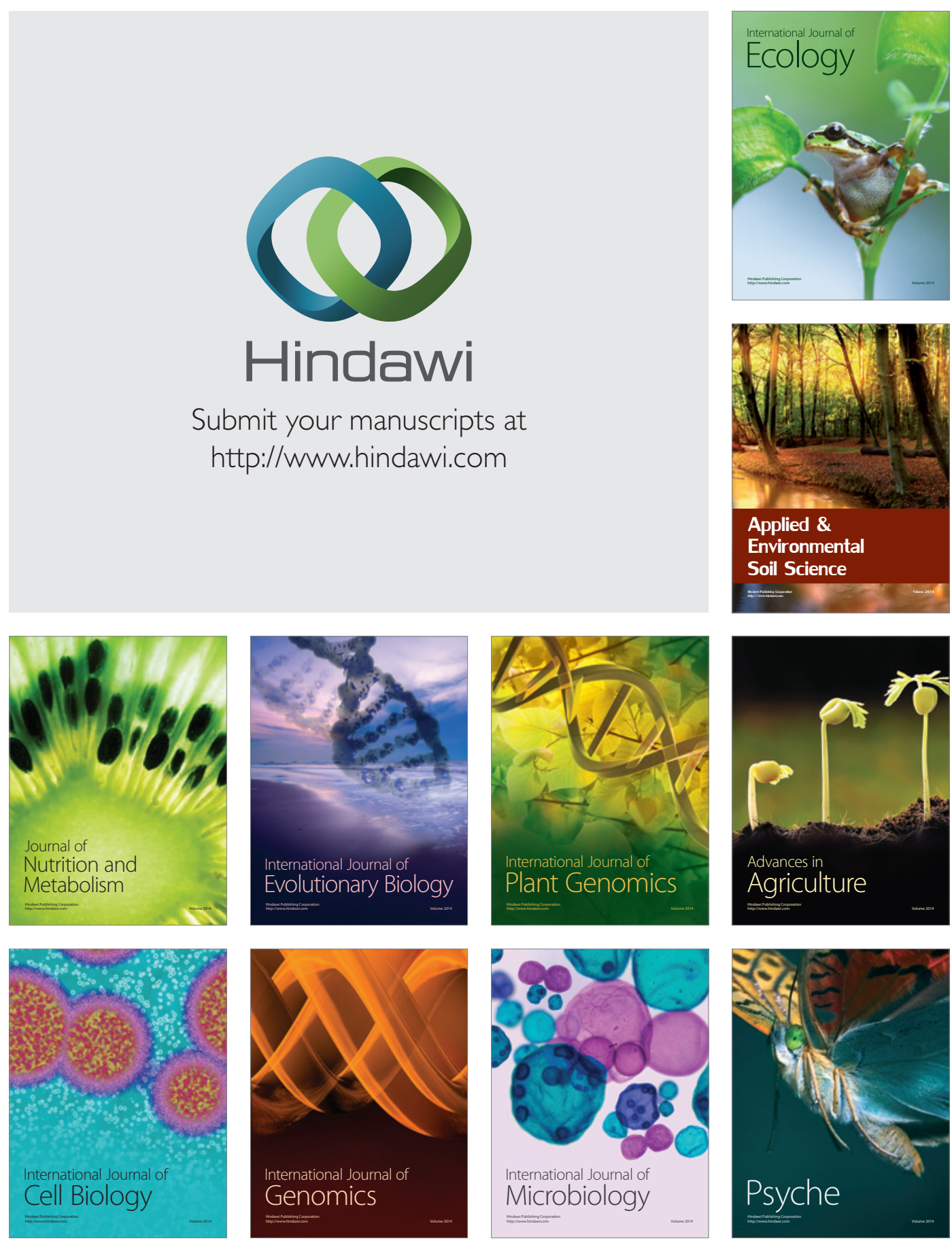